\title{
The Effect of Viral Diseases of Large Cardamom (Amomum subulatum Roxb.) on Production and their Management
}

\author{
Jiwan Paudel", Saroj Belbase, Sakar Gautam, Rivesh Bhusal and Shrvan Kumar
}

RGSC, Institute of Agricultural Science, Banaras Hindu University, Varanasi, (U.P), India

*Corresponding author

\section{A B S T R A C T}

\begin{tabular}{|l|}
\hline Ke y w o r d s \\
$\begin{array}{l}\text { Large cardamom } \\
\text { (Amomum subulatum), } \\
\text { Chirke, Foorkey, } \\
\text { Pentalonia nigronervosa, } \\
\text { Ropalosiphum maidis }\end{array}$ \\
\hline Article Info \\
\hline $\begin{array}{l}\text { Accepted: } \\
\text { 07 February } 2018 \\
\text { Available Online: } \\
\text { 10 March 2018 }\end{array}$ \\
\hline \hline
\end{tabular}

Large Cardamom is common cultivated spice crop in Nepal as well as in India and Bhutan. Large Cardamom is prone to many diseases, among them viral diseases are annihilative which causes sententious yield loss. Field surveys were conducted during different seasons of 2016-17. Chirke is serious as far as rate of spread is concerned and Foorkey is serious as far as yield loss is concerned. Chirke is caused by Large Cardamom Chirke Virus (LCCV), a new virus species under the genus Macluravirus, family Potyviridae and is characterized by mosaic with pale streak on the leaves. The streaks turn pale brown resulting in drying, withering of leaves and finally death of the plants. The flowering in diseased plants is debased. The chirke disease is transmitted by mechanical sap inoculation and also by aphid (Ropalosiphum maidis Fitch). The cultivar Kopringe is resistant to chirke. Excessive sprouting and formation of bushy dwarf clumps at the base of the mother plants that gradually die, characterize the foorkey disease caused by Cardamom Bushy Dwarf Virus (CBDV). The primary promulgation of the disease from one area to another is through infected rhizomes and further spread within the plantation by aphids, Pentalonia nigronervosa Cog., Micromyzus kalimpongensis (Hemiptera: Aphididae).

\section{Introduction}

Large cardamom (Amomum subulatum Roxb.), also known as the "Queen of spices", belonging to Zingiberaceae family is the most prominent cash crop, appealing high revenues across the globe. Nepali laborers in Sikkim, India, introduced cardamom to Illam district during the 19th century. The large cardamom plant is a perennial herb with subterranean rhizomes with leafy shoots. Stem is a pseudostem which is called tiller. Inflorescence is spike. Generally, 30 to 40 flowers are observed in a spike. Flowers are yellow, bisexual, zygomorphic and pollinated by bumble bees. Anthesis occurs in the morning hours. Fruit is a capsule, achinated, maroon in colour with seeds which are whitish in immature stage and dark brown to black in mature stage generally contains moisture $8.5 \%$, protein $6 \%$, volatile oil $2.8 \%$, crude fiber $22 \%$, starch $43.2 \%$, ether extract $5.3 \%$ and alcohol extract 7\% (Shankaracharya et al., 1990). Additionally, $100 \mathrm{gm}$ of large cardamom seeds contains $666.6 \mathrm{mg}$ calcium, $412.5 \mathrm{mg}$ magnesium, $61 \mathrm{mg}$ phosphorous and 14.4 parts per million fluoride (Bhandari et al., 2013). Medicinally, cardamom seeds have 
diuretic, antidote for snake and scorpion venom, stimulant, stomachic, alexipharmic and astringent properties (Gopal et al., 2012). Cardamom capsules and seeds are used to treat gonorrhea, congestive jaundice, headache, and stomatitis and to control insects (URL- 1).

Large cardamom is a seophyte i.e. a shadeloving plant. It is a crop of humid sub-tropics and a semi-evergreen plant. It is naturally found in the steep hills of eastern subHimalayan region which receive a welldistributed rainfall spread around 200 days with a total of about $3,000-3,500 \mathrm{~mm} /$ year. Large cardamom grows up to $600-2,350 \mathrm{~m}$ above mean sea level. Large cardamom is commercially cultivated in lower altitudes of cooler areas and higher altitudes of warmer areas. Cardamom plants remain dormant during winters and it can withstand up to $2^{\circ} \mathrm{C}$ but the plant is susceptible to frost injury. The flower bud differentiation occurs from August in lower altitudes to October in higher altitudes.

The initiation of flower buds occur before winter on lower elevations but further development takes place only after the lapse of cold period in early-March. Rains during flowering is detrimental, as it hampers foraging activity of the pollinating bees, affecting the sensitive flowers and resulting in poor capsule setting and barren spikes. Cardamom starts to benefit economically from $3^{\text {rd }}$ year of its plantation and the optimal yield is obtained between 8- 10 years. However its total life span is about 20-25years (URL-2).

Nepal is the world's largest cardamom producer (Avasthe et al., 2011; Pothula and Singh, 2013), with a total of 5,763 MT of cardamom, worth Rs. 2,528 million or about US\$23.6 million, on about 14,847 ha of land in 40 districts and 15700 ha of land with production of 6439 MT of Cardamom in
2016-17 (Singh, 2016-17), with cost benefit ratio of $1: 10$.

\section{Materials and Methods}

Field surveys were conducted in distinctive seasons from July 2016 to March 2017. The farmers namely Tikaram Paudel (3.5 ha), Kedar Acharya (5 ha), Rangkhanipahi (6 Baglung) were the integral part of the survey. The areas throughout was taken by them and helped in recording data of the yield loss of the cardamom. The field visit and inspection for the diseases, chirke and foorke was done from 35 plants of every location. The plantations affected by the diseases were recorded in the area $10 \mathrm{~m} \times 10 \mathrm{~m}$ in dimension. The yield of that scrupulous dimension not affected by any diseases weres recorded. Lastly the yield loss \% was calculated and the dataare interpreted in table 1 and 2.

\section{Results and Discussion}

Chirke disease spoliation varied from $0.0 \%$ to $17.14 \%$ and foorkey disease spoliation varied from $0.0 \%$ to $37.14 \%$ in various plantation in Baglung District (Table 1). A high incidence (37.2-39.3\%) of foorkey was recorded in certain plantations in the Darjeeling hills located at lower altitudes (300-1380 m) by Mandal et al., (2013) also. Therefore, chirke disease yield loss varied from $33.97 \%$ to $52.84 \%$ and foorkey disease yield loss varied from $36.30 \%$ to $55.47 \%$ in various large cardamom plantation area. Whereas, maximum chikey disease yield loss was found in Rangkhani and furkey disease yield loss was obtained in Painyu. Minimum chirkey and furkey yield loss of large cardamom was reported in Chisti (Table 2).

The minimization of these diseases can escalate the production of farmers by more than 50\%, which can also increase the economic status by exporting it. The future 
research should be concerned on minimization of these diseases using the simple, economical and effective measures, which can be easily implemented by the farmers.

\section{Chirke disease}

\section{The virus}

The virus consists of polyhedral particles measuring $40 \mathrm{~nm}$ diameters. It has a thermal inactivation point of $50-60^{\circ} \mathrm{C}$ for $10 \mathrm{~min}$, withstands a dilution up to 1:5000 and the longevity in vitro is about 4-8 days. A new virus species large cardamom chirke virus (LCCV) under the genus Macluravirus, family Potyviridae has been characterized (Mandal et al., 2012).

\section{Etiology}

The 3' terminal genome sequence of the virus associated with chirke disease was revealed and found phylogenetically close to CdMV under the genus Macluravirus, family Potyviridae (Jacob and Usha, 2001)

\section{Symptoms}

The symptoms of chirke disease are delineate by streak mosaic on the tender leaves with dark green streaks in the light green background of the lamina.

In the rigorously affected plant, the mosaic streaks coalesce and the leaf gradually turns brown and dries up subsequently (Plate-1).

\section{Loss Yield}

The affected clump produces less number of flowers and thus causes a serious loss in yield. Raychowdhury and Ganguly (1965a, b) experimentally showed that the loss due to the virus was as high as $85.20 \%$ and $80.09 \%$.

\section{Foorkey disease of large cardamom}

In Nepalese, foorkey means bushy. The virus belongs to the genus Nanovirus and family Nanoviridae (Mandal et al., 2004).

\section{Transmission}

The foorkey is not sap transmissible. Varma and Capoor (1964) reported that at Poona, the foorkey was readily transmitted by the banana aphid, Pentalonia nigronervosa in a persistent manner. Later, Basu and Ganguly (1968) reported that at Kalimpong, the foorkey was transmitted by another aphid, Mycromyzus kalimpongensis Basu, but not by the banana aphid.

\section{Etiology}

A few isometric particles of 17 to $20 \mathrm{~nm}$ were found to be associated with the diseased plants. Mandal and his colleagues (Mandal et al., 2004)

For the first time reported association of a nanovirus with the foorkey disease of large cardamom based on the nucleotide sequence of replication associated protein gene (Rep), which showed $80-82 \%$ identity with BBTV and from $47.6 \%$ to $48.5 \%$ identity with other nanoviruses.

\section{Symptoms}

Pronounced stunting and formation of numerous minute tillers which fail to form inflorescence.

The tillers do not grow beyond a few inches in height and appear bushy.

\section{Yield loss}

Varma and Capoor (1964) recorded crop damages ranging from 8.7 to 93.9 percent. 
Table.1 Chirke and Foorkey diseases incidence at different location

\begin{tabular}{|c|c|c|c|c|c|c|}
\hline S.No & Location & $\begin{array}{l}\text { No. of } \\
\text { plantation } \\
\text { surveyed }\end{array}$ & $\begin{array}{l}\text { Plants } \\
\text { affected by } \\
\text { Chirkey } \\
\text { disease }\end{array}$ & $\begin{array}{l}\text { Chirke } \\
\text { diseases } \\
\text { incidence }\end{array}$ & $\begin{array}{l}\text { Plants } \\
\text { affected by } \\
\text { Foorkey } \\
\text { disease }\end{array}$ & $\begin{array}{l}\text { Foorkey } \\
\text { diseases } \\
\text { incidence }\end{array}$ \\
\hline \multirow{4}{*}{1} & \multirow{4}{*}{ Chisti, Baglung } & \multirow{4}{*}{4} & i) 2 & 5.71 & i) 7 & 20.00 \\
\hline & & & ii) 1 & 2.86 & ii) 3 & 8.57 \\
\hline & & & iii) 0 & 0.00 & iii) 4 & 11.43 \\
\hline & & & iv) 2 & 5.71 & iv) 0 & 0.00 \\
\hline \multirow{3}{*}{2} & \multirow{3}{*}{$\begin{array}{l}\text { Damek, } \\
\text { Baglung }\end{array}$} & \multirow{3}{*}{3} & i) 3 & 8.57 & i) 4 & 11.43 \\
\hline & & & ii) 2 & 5.71 & ii) 3 & 8.57 \\
\hline & & & iii) 5 & 14.29 & iii) 7 & 20.00 \\
\hline \multirow{3}{*}{3} & \multirow{3}{*}{$\begin{array}{l}\text { Painyu, } \\
\text { Baglung }\end{array}$} & \multirow{3}{*}{3} & i) 1 & 2.86 & i) 10 & 28.57 \\
\hline & & & ii) 4 & 11.43 & ii) 13 & 37.14 \\
\hline & & & iii) 0 & 0.00 & iii) 7 & 20.00 \\
\hline \multirow[b]{2}{*}{4} & \multirow[b]{2}{*}{$\begin{array}{l}\text { Dhuseni, } \\
\text { Baglung }\end{array}$} & \multirow[b]{2}{*}{2} & i) 2 & 5.71 & i) 5 & 14.29 \\
\hline & & & ii) 3 & 8.57 & ii) 9 & 25.71 \\
\hline \multirow[b]{2}{*}{5} & \multirow{2}{*}{$\begin{array}{l}\text { Rangkhani, } \\
\text { Baglung }\end{array}$} & \multirow[b]{2}{*}{2} & i) 6 & 17.14 & i) 8 & 22.86 \\
\hline & & & ii) 2 & 5.71 & ii) 12 & 34.29 \\
\hline
\end{tabular}

Note: The roman numerals represent the plantation field under survey, 35 plants a particular location

\begin{tabular}{|l|l|l|l|l|l|}
\hline \multicolumn{5}{|c|}{ Table.2 Yield loss due to Chirke and Foorkey diseases in Large cardamom } \\
\hline Particulars & $\begin{array}{l}\text { Average field } \\
\text { productivity } \\
\text { (in Kg) }\end{array}$ & $\begin{array}{l}\text { Average of } \\
\text { Chirke } \\
\text { affected } \\
\text { field } \\
\text { productivity } \\
\text { (in Kg) }\end{array}$ & $\begin{array}{l}\text { Average of } \\
\text { Foorkey } \\
\text { affected field } \\
\text { productivity } \\
\text { (in Kg) }\end{array}$ & $\begin{array}{l}\text { Yield loss } \\
\text { by chirkey } \\
\text { disease (in } \\
\text { \%) }\end{array}$ & $\begin{array}{l}\text { Yield loss } \\
\text { by foorkey } \\
\text { disease } \\
\text { (in \%) }\end{array}$ \\
\hline Area & 4.71 & 3.10 & 3.00 & 33.97 & 36.30 \\
\hline Chisti & 5.58 & 2.80 & 2.73 & 49.82 & 51.07 \\
\hline Damek & 5.84 & 3.62 & 2.60 & 38.01 & 55.47 \\
\hline Painyu & 6.67 & 4.25 & 3.80 & 36.28 & 43.02 \\
\hline Dhuseni & 4.92 & 2.32 & 2.70 & 52.84 & 52.84 \\
\hline Rangkhani & 4.32 & & \\
\hline Note: Weight above is referred to dry weight of capsule, Area= & & & & \\
\hline
\end{tabular}




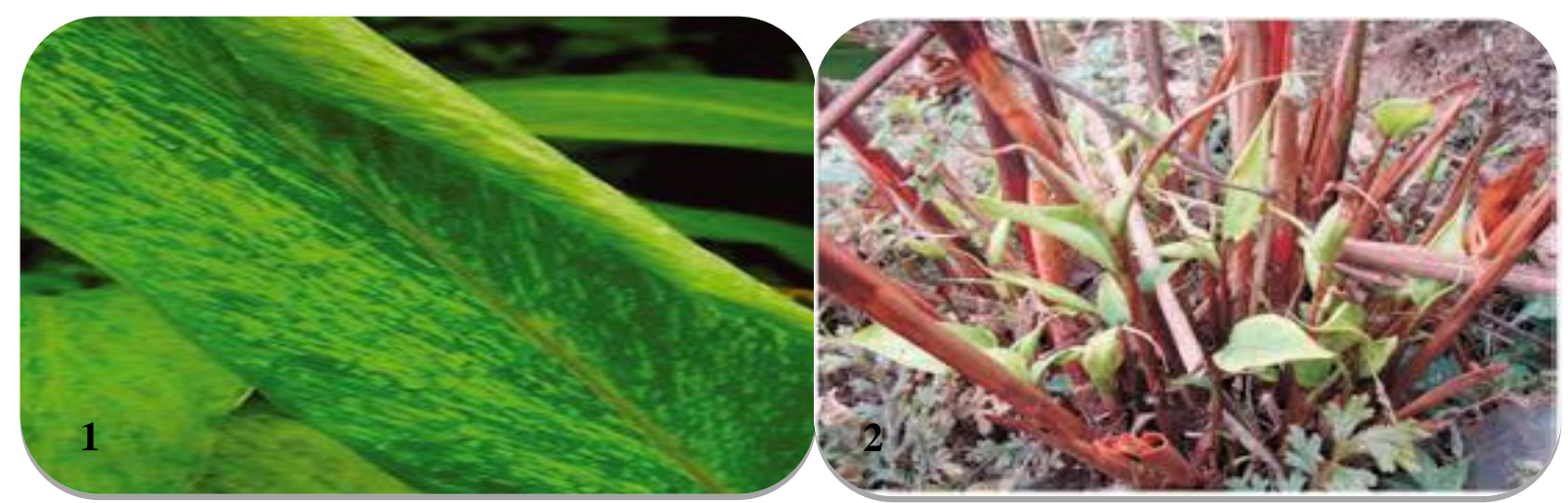

Plate.1 Symptom on leaf 1) Chirke disease and 2) on stem Foorkey disease

\section{Control}

Time to time extirpate of the diseased plants with their plenishment of certified virus free plants is essential for the management of chirke disease (Raychowdhury and Ganguly 1965a).

To use Bebo variety resistant to foorkey viral infection and Ramla moderately tolerant to chirkey but susceptible to foorkey disease (URL-2).

Treatment of rhizomes @ $0.075 \%$ hydroquinone and soil drenching with $0.1 \%$ of thiouracil showed virus inhibition.

Varma and Capoor (1964) showed that injection of a few milliliters of Agrozone-40 into the infected rhizomes caused withering that facilitated the easy lifting of the clump. Use healthy planting material can control foorkey disease.

Commercially available formulation of insectpathogenic fungi (Beauveria bassiana) Mycotrol or Biosoft @ 3.0g/l, Vertalec or Inovert or Biocatch (Verticillum lecanii) @ 3.0g/l, Prioroty (Paecelomyces fumosoroseus) @ $2.5 \mathrm{ml} / 1$ should be apply.

Application of Cohigan (Imidacloprid17.8 SL)@ $1 \mathrm{ml} / 1$ or Aktara or 7Star(Thiamethoxam25 WG) @1 g/3 liter of water ormetasystox25EC @ 1ml/ L or Polar (Acetamiprid 20SP) @0.5g/l should be apply. Two applications of foliar sprays, a week apart, are often needed.

The Loss due to Chirke and Foorkey should be immediately cut down to size in order to ensure the good production of large cardamom. Nevertheless, having strength and opportunities in cardamom industry in Nepal, some of the uncertainties exist too. Such as decline labor inputs, reoccurrence of diseases and pests, vague price fixation mechanism, incremental use of chemicals and if no international trade, impaired domestic consumption, seriously threatening the cardamom industry, which compelled to higher attention. Another reason, Nepalese cardamom has not good market access in SAARC countries except India. The highest tariff is applying by Bhutan which is 35\% followed by Bangladesh which is $23.75 \%$. Nevertheless, world's top importers like UAE, Singapore, India and other are providing $0 \%$ tariff to the Nepalese cardamom (Singh, 2016-17).

\section{References}

Avasthe RK, Singh KK and Tomar JMS (2011). Large cardamom (Amomum subulatum Roxb.) based agroforestry systems for production, resource conservation and livelihood security in 
the Sikkim Himalayas. Indian $J$ Soil Conserv., 39(2): 155-160.

Basu A.N., and Ganguly B. 1968. A note on transmission of 'Foorkey disease' of large cardamom by the aphid, Micromyzus kalimpongensis Basu. Ind. Phytopath., 21: 127

Bhandari, A.K., Bisht, V.K., Negi, J.S. and Baunthiyal, M. 2013. 1, 8-Cineole: A predominant component in the essential oil of large cardamom (Amomum subulatum Roxb.). J.Med. Plants Res, 7(26): 1957-1960.

Gopal, K., Baby, C. and Mohammed, A. 2012.AmomumSubulatumRoxb: An overview in all aspects. Int Res $J$ Pharm, 3(7): 96-99.

Jacob T. and Usha R. 2001. 3'-Terminal sequence analysis of the RNA genome of the Indian isolate of cardamom mosaic virus: a new member of genus Maclura virus of Potyviridae. Virus Genes, 23: 81-88.

Mandal B, Mandal S, Pun KB and Varma A. 2004. First report of Association of Nanovirus with Foorkey disease of large cardamom in India. $\mathrm{Pl} \mathrm{Dis} \mathrm{88:}$ 428.

Mandal B, VijayanandrajS, Shilpi S, Pun KB, Singh V, Pant RP, Jain RK, Varadarasan S, Varma A (2012) Disease distribution and characterisation of a new macluravirus associated with chirke disease of large cardamom. Ann ApplBiol 160:225-236

Mandal, B., Shilpi, S., Barman, A.R., Mandal, S. and Varma, A., 2013. Nine novel DNA components associated with the foorkey disease of large cardamom:
Evidence of a distinct babuvirus species in Nanoviridae. Virus research, 178(2), 297-305.doi:

10.1016/j.virusres.2013.09.027. Epub 2013 Oct 1.

Pothula AK and Singh AI (2013) Postharvest Processing of Large Cardamom in the Eastern Himalaya. Mt ResDev, 33(4): 453-462. DOI: 10.1659/MRDJOURNAL-D-12-00069.1

Raychowdhury, S.P. and Ganguly, B. 1965a. Transmission of chirkey disease of large cardamom by aphid species. Indian $J$. Ent. 27: 272-276.

Raychowdhury, S.P. and Ganguly, B. 1965b. Further studies on chirkey disease of large cardamom (Amomum subulatum Roxb.). Indian Phytopathology 18: 373377.

Shankaracharya, N.B., Raghavan, B., Abraham, K.O. and Shankaranarayana, M.L. 1990. Large cardamom chemistry, technology and uses. Spice India, 3(8):17-25.

Singh D. (2016-17). Economic survey, Fiscal Year 2016/17, Ministry of Finance, Government of Nepal (GoN), Kathmandu. pp. 1-426.

URL-1:

https://www.bimbima.com/ayurveda/gre ater-cardamom-benefits-and-medicinaluses/359/

URL-2:

http://agricare.kisanhelp.in/content/large -cardamom-cultivation-india

Varma P.M. and Capoor S.P.1964 Foorkey disease of large cardamom. Indian $\mathrm{J}$. Agric. Sci. 34: 56-62.

\section{How to cite this article:}

Jiwan Paudel, Saroj Belbase, Sakar Gautam, Rivesh Bhusal and Shrvan Kumar. 2018. The Effect of Viral Diseases of Large Cardamom (Amomum subulatum Roxb.) on Production and their Management. Int.J.Curr.Microbiol.App.Sci. 7(03): 855-860.

doi: https://doi.org/10.20546/ijcmas.2018.703.100 